\title{
Synthesis and evaluation of dibenzothiophene analogues as Pin1 inhibitors for cervical cancer therapy
}

Ke-Jia Wu, ${ }^{\perp \dagger}$ Xie Liu, ${ }^{\perp \ddagger}$ Suk-Yu Wong, ${ }^{\S}$ Yuyang Zhou, ${ }^{* \ddagger}$ Dik-Lung Ma, ${ }^{\S}$ Chung-Hang Leung* ${ }^{* \dagger}$

† State Key Laboratory of Quality Research in Chinese Medicine, Institute of Chinese Medical Sciences, University of Macau, Macao, China

$¥$ School of Chemistry, Biology and Material Engineering, Suzhou University of

Science and Technology, No.1 Kerui Road, Suzhou New District, Jiangsu, 215009,

China

§Department of Chemistry, Hong Kong Baptist University, Kowloon Tong, Hong Kong, China

${ }^{\perp}$ These authors contributed equally to this work.

Corresponding author:

Chung-Hang Leung, Institute of Chinese Medical Sciences, University of Macau, Taipa, Macau, Tel: (+853) 8822-4688, Email: duncanleung@um.edu.mo

Yuyang Zhou, School of Chemistry, Biology and Material Engineering Suzhou University of Science and Technology No.1 Kerui Road, Suzhou New District, Jiangsu, 215009, China, Email: zhouyuyang@mail.usts.edu.cn

Dik-Lung Ma, Department of Chemistry, T1303, Hong Kong Baptist University, Kowloon Tong, Hong Kong, Tel: (852) 9251 0870, Email: edmondma@hkbu.edu.hk

\section{Experimental Section}

Synthesis and characterization.

4-bromodibenzo[b,d]thiophene (Yield: 68\%). This compound is synthesized according to the former reported method. ${ }^{1}{ }^{1} \mathrm{H}$ NMR (DMSO-d $6,400 \mathrm{MHz}$ ). $\delta \mathrm{ppm}$ : 8.45-8.38 (m, $2 \mathrm{H}), 8.13-8.09(\mathrm{~m}, 1 \mathrm{H}), 7.80-7.76(\mathrm{dd}, \mathrm{J}=7.6,0.8 \mathrm{~Hz}, 1 \mathrm{H}), 7.62-7.55$ $(\mathrm{m}, 2 \mathrm{H}), 7.50(\mathrm{t}, \mathrm{J}=8 \mathrm{~Hz}, 1 \mathrm{H}) .{ }^{13} \mathrm{C}$ NMR $\left(\mathrm{DMSO}_{-} \mathrm{d}_{6}, 101 \mathrm{MHz}\right), \delta \mathrm{ppm}: 140.00$, $137.84,136.49,135.48,129.55,127.73,126.59,125.24,123.16,122.86,121.24$, 115.44, 39.50. GC-MS, m/z calculated. 263.9, experimental. 263.9.

1-(dibenzo[b,d]thiophen-4-yl)-1H-imidazole (Yield: $80 \%$ ). A mixture of 4bromodibenzo[b,d]thiophene (20 mmol), $1 \mathrm{H}$-imidazole $(24 \mathrm{mmol}), \mathrm{K}_{2} \mathrm{CO}_{3}(40 \mathrm{mmol})$, Cul $(0.5 \mathrm{mmol})$, and $L$-proline $(4 \mathrm{mmol})$ in $50 \mathrm{~mL}$ of DMF was heated for 48 hours at $90{ }^{\circ} \mathrm{C}$. The cooled mixture was partitioned between water and dichloromethane. The organic layer was separated, and the aqueous layer was extracted with dichloromethane. The combined organic layers were washed with water, dried over anhydrous $\mathrm{Na}_{2} \mathrm{SO}_{4}$, and concentrated in vacuo. The residual oil was loaded on a silica gel column and eluted with the mixture solution of dichloromethane/petroleum ether to afford purified product. ${ }^{1} \mathrm{H}$ NMR (DMSO- $\left.\mathrm{d}_{6}, 400 \mathrm{MHz}\right) . \delta \mathrm{ppm}:$ 8.50-8.45 (m, $2 \mathrm{H}), 8.20(\mathrm{~d}, \mathrm{~J}=0.8 \mathrm{~Hz}, 1 \mathrm{H}), 8.11-8.00(\mathrm{~m}, 1 \mathrm{H}), 7.75(\mathrm{~d}, \mathrm{~J}=1.2 \mathrm{~Hz}, 1 \mathrm{H}), 7.72-7.64$ $(\mathrm{m}, 2 \mathrm{H}), 7.60-7.56(\mathrm{~m}, 2 \mathrm{H}), 7.24(\mathrm{~d}, \mathrm{~J}=0.8 \mathrm{~Hz}, 1 \mathrm{H}) .{ }^{13} \mathrm{C}$ NMR (DMSO-d $\left.6,101 \mathrm{MHz}\right)$, $\delta$ ppm: 138.54, 137.74, 137.45, 135.38, 133.86, 132.84, 130.19, 128.33, 126.57, 
125.77, 123.62, 123.11, 123.05, 122.09, 120.02. GC-MS, m/z calculated 250.1, experimental, 250.1.

1-(dibenzo[b,d]thiophen-4-yl)-1H-benzo[d]imidazole (Yield: 78\%). This compound is synthesized using the same procedure of 1-(dibenzo[b,d]thiophen-4-yl)-1Himidazole with $1 \mathrm{H}$-benzo[d]imidazole in the place of $1 \mathrm{H}$-imidazole. ${ }^{1} \mathrm{H}$ NMR $\left(\mathrm{CDCl}_{3}\right.$, $400 \mathrm{MHz}) . \delta$ ppm: 8.35-8.20 (m, $3 \mathrm{H}), 7.97(\mathrm{~d}, \mathrm{~J}=8 \mathrm{~Hz}, 1 \mathrm{H}), 7.86-7.83(\mathrm{~m}, 1 \mathrm{H}), 7.70-$ $7.66(\mathrm{t}, \mathrm{J}=8 \mathrm{~Hz}, 1 \mathrm{H}), 7.60-7.53(\mathrm{~m}, 3 \mathrm{H}), 7.45-7.32(\mathrm{~m}, 3 \mathrm{H}) .{ }^{13} \mathrm{C}$ NMR $\left(\mathrm{CDCl}_{3}, 101\right.$ $\mathrm{MHz})$. $\delta$ ppm: 143.73, 142.31, 139.13, 138.18, 136.51, 135.28, 133.67, 131.08, $127.69,125.57,125.01,124.13,123.62,123.00,122.95,122.06,121.79,120.73$, 110.97 .

1-(dibenzo[b,d]thiophen-2-yl)-1H-imidazole (Yield: 77\%). This compound is synthesized using the same procedure of 1 -(dibenzo[b,d]thiophen-4-yl)-1H-imidazole with 2-bromodibenzo[b,d]thiophene in the place of 4-bromodibenzo[b,d]thiophene. ${ }^{1} \mathrm{H}$ NMR (DMSO- $\left.\mathrm{d}_{6}, 400 \mathrm{MHz}\right) . \delta \mathrm{ppm}: 8.71(\mathrm{~d}, \mathrm{~J}=2 \mathrm{~Hz}, 1 \mathrm{H}), 8.53-8.49(\mathrm{~m}, 1 \mathrm{H}), 8.417$ (s, $1 \mathrm{H}), 8.18(\mathrm{~d}, \mathrm{~J}=8.4 \mathrm{~Hz}, 1 \mathrm{H}), 8.08(\mathrm{~m}, 1 \mathrm{H}), 7.92(\mathrm{t}, \mathrm{J}=1.2 \mathrm{~Hz}, 1 \mathrm{H}), 7.85-7.82$ (dd, $\mathrm{J}=8.4,2.4 \mathrm{~Hz}, 1 \mathrm{H}), 7.58(\mathrm{~m}, 2 \mathrm{H}), 7.18(\mathrm{~s}, 1 \mathrm{H}) .{ }^{13} \mathrm{C}$ NMR (DMSO-d $\left.\mathrm{d}_{6}, 101 \mathrm{MHz}\right), \delta$ ppm: 140.04, 137.07, 136.67, 136.31, 135.15, 134.92, 130.36, 128.12, 125.29, $124.74,123.66,123.11,120.19,118.87,114.16$.

4-(1H-imidazol-1-yl)dibenzo[b,d]thiophene 5-oxide (Yield: 93\%). $15 \mathrm{~g}$ hydrogen peroxide (30 wt\%) was slowly dropped into $30 \mathrm{~mL}$ glacial acetic acid solution of 1(dibenzo[b,d]thiophen-4-yl)-1H-imidazole $(14 \mathrm{mmol})$ at $0{ }^{\circ} \mathrm{C}$. After the addition, the temperature is raised to room temperature and the mixture solution are still kept stirring until the starting materials are almost consumed (TLC detection). The mixture solution was neutralized with $10 \mathrm{wt} \%$ aq. $\mathrm{NaHCO}_{3}$ solution. Then, the solution was extracted with dichloromethane and the organic phase are dried with anhydrous $\mathrm{Na}_{2} \mathrm{SO}_{4}$. The concentrated organic phase is purified using silica gel column chromatography with an eluent solution of dichloromethane/petroleum ether and the ideal product is received as white powder. Notice. A few amount of $4-(1 \mathrm{H}$-imidazol-1$\mathrm{yl}$ )dibenzo[b,d]thiophene 5,5-dioxide (1c) was also eluted out from the silica gel column and collected before the 4- $(1 \mathrm{H}$-imidazol-1-yl)dibenzo[b,d]thiophene 5-oxide. ${ }^{1} \mathrm{H} \mathrm{NMR}\left(\mathrm{CDCl}_{3}, 400 \mathrm{MHz}\right) . \delta$ ppm: $8.12(\mathrm{~s}, 1 \mathrm{H}), 8.00(\mathrm{~d}, \mathrm{~J}=7.6 \mathrm{~Hz}, 1 \mathrm{H}), 7.91-7.86$ $(\mathrm{m}, 2 \mathrm{H}), 7.75(\mathrm{t}, \mathrm{J}=8 \mathrm{~Hz}, 1 \mathrm{H}), 7.70-7.65(\mathrm{~m}, 2 \mathrm{H}), 7.60(\mathrm{~m}, 1 \mathrm{H}), 7.43(\mathrm{dd}, \mathrm{J}=8,0.8$ $\mathrm{Hz}, 1 \mathrm{H}), 7.33(\mathrm{~s}, 1 \mathrm{H}) .{ }^{13} \mathrm{C} \mathrm{NMR}\left(\mathrm{CDCl}_{3}, 101 \mathrm{MHz}\right) . \delta \mathrm{ppm}: 144.65,140.12,138.47$, $138.09,136.31,134.38,132.84,130.74,130.51,127.53,125.24,122.27,121.21$, 121.14. Tof-MS, $\mathrm{m} / \mathrm{z}$ calculated 267.0587, experimental, 267.0592.

4-(1H-benzo[d]imidazol-1-yl)dibenzo[b,d]thiophene 5-oxide (Yield: $87 \%)$. This compound was synthesized using the same procedure of $4-(1 \mathrm{H}$-imidazol-1yl)dibenzo[b,d]thiophene 5-oxide just with $1 \mathrm{H}$-benzo[d]imidazole in the place of $1 \mathrm{H}$ imidazole. ${ }^{1} \mathrm{H}$ NMR $\left(\mathrm{CDCl}_{3}, 400 \mathrm{MHz}\right)$. $\delta$ ppm: $8.69(\mathrm{~s}, 1 \mathrm{H}), 8.05-7.98(\mathrm{~m}, 3 \mathrm{H}), 7.93$ (d, J=8 Hz, $1 \mathrm{H}), 7.85$ (t, J=8 Hz, $1 \mathrm{H}), 7.70$ (t, J=7.2 Hz, $1 \mathrm{H}), 7.61(\mathrm{~m}, 2 \mathrm{H}), 7.48-$ 7.40 (m, $3 \mathrm{H}) .{ }^{13} \mathrm{C} \mathrm{NMR}\left(\mathrm{CDCl}_{3}, 101 \mathrm{MHz}\right) . \delta \mathrm{ppm}: 144.74,140.71,140.49,136.06$, $134.60,133.08,130.78,127.74,126.99,125.31,124.90,122.69,122.48,119.60$, 111.17.

2-(1H-imidazol-1-yl)dibenzo[b,d]thiophene 5-oxide (Yield: 90\%). This compound was synthesized using the same procedure of the $4-(1 \mathrm{H}$-imidazol-1yl)dibenzo[b,d]thiophene 5-oxide just with 1-(dibenzo[b,d]thiophen-2-yl)-1H-imidazole in the place 1-(dibenzo[b,d]thiophen-4-yl)-1H-imidazole. ${ }^{1} \mathrm{H} \mathrm{NMR}\left(\mathrm{CDCl}_{3}, 400 \mathrm{MHz}\right)$.

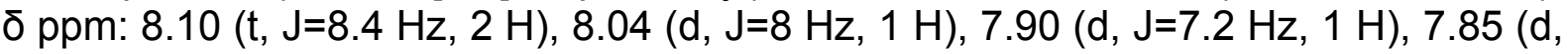
$\mathrm{J}=2 \mathrm{H}, 1 \mathrm{H}), 7.68(\mathrm{td}, \mathrm{J}=7.6,1.2,1 \mathrm{H}), 7.61(\mathrm{td}, \mathrm{J}=7.6,1.2,1 \mathrm{H}), 7.54(\mathrm{dd}, \mathrm{J}=8.4,2 \mathrm{~Hz}$, $1 \mathrm{H}), 7.42$ (s, $1 \mathrm{H}), 7.31$ (s, $1 \mathrm{H}) .{ }^{13} \mathrm{C}$ NMR $\left(\mathrm{CDCl}_{3}, 101 \mathrm{MHz}\right) . \delta \mathrm{ppm}:$ 146.07, 143.78, 
141.02, 139.50, 135.83, 135.58, 132.85, 131.30, 130.53, 129.27, 127.80, 122.24, $121.99,118.07,114.51$.

Compound 1a (Yield:95\%). $5 \mathrm{mmol}$ (bromomethyl)benzene was added in to $20 \mathrm{~mL}$ acetonitrile solution of compound $1 \mathrm{c}(1 \mathrm{mmol})$ and the mixture solution was stirred for 24 hours under argon atmosphere at room temperature. And then, removing $\mathrm{CH}_{3} \mathrm{CN}$ from the mixture solution under vacuum and adding methanol and $5 \mathrm{mmol} \mathrm{KI}$ to the residues, which was followed by stirring for another 12 hours at room temperature. Then, the solvent was removed by rotary evaporator. The inorganic salt in the residual oil was removed by extraction and the organic phase was collected together and dried over anhydrous $\mathrm{Na}_{2} \mathrm{SO}_{4}$. After the filtration and concentrated under reduced pressure, the crude product was purified by recrystallization with $n$ hexane/methanol. ${ }^{1} \mathrm{H}$ NMR (DMSO-d 6 , $400 \mathrm{MHz}$ ). $\delta$ ppm: $9.96(\mathrm{~s}, 1 \mathrm{H}), 8.52(\mathrm{~d}, \mathrm{~J}=8$ $\mathrm{Hz}, 1 \mathrm{H}), 8.27(\mathrm{~s}, 1 \mathrm{H}), 8.17-8.06(\mathrm{~m}, 3 \mathrm{H}), 8.00(\mathrm{~d}, \mathrm{~J}=8 \mathrm{~Hz}, 1 \mathrm{H}), 7.92(\mathrm{t}, \mathrm{J}=8 \mathrm{~Hz}, 1 \mathrm{H})$, 7.75(t, J=7.6 Hz, $1 \mathrm{H}), 7.46(\mathrm{~m}, 5 \mathrm{H}), 5.66(\mathrm{~s}, 2 \mathrm{H}) .{ }^{13} \mathrm{C} \mathrm{NMR}$ (DMSO-d $\left.6,101 \mathrm{MHz}\right) . \delta$ ppm: $138.03,136.52,136.36,135.35,134.20,133.19,132.06,131.33,130.34$,
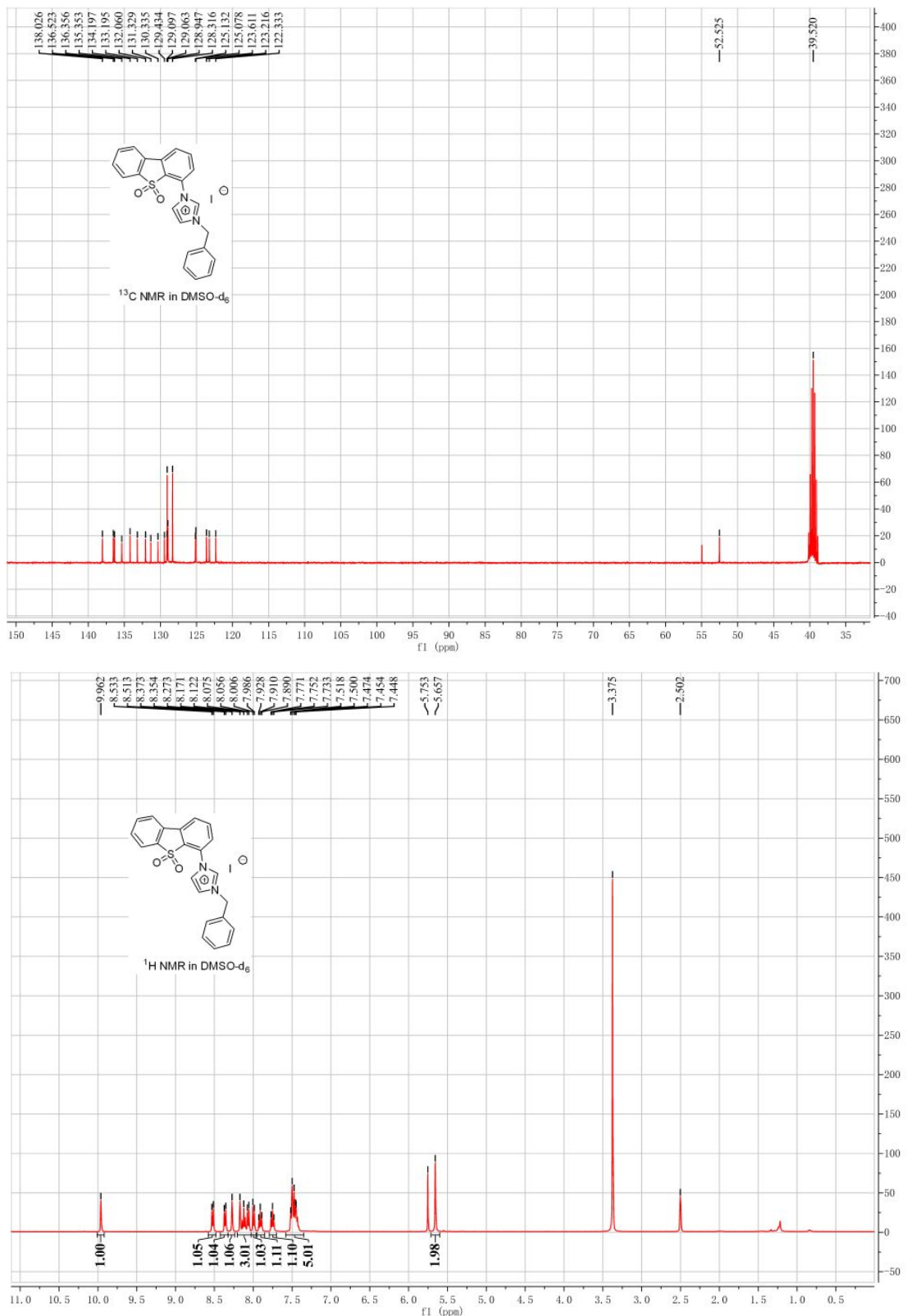
$129.43,129.10,129.06,128.95,128.32,125.13,125.08,123.61,123.22,122.33$, 52.53. Tof-MS. [M-I] ${ }^{+}, \mathrm{m} / \mathrm{z}$ calculated 373.1005 , experimental 373.1006.

Compound 1b (Yield: $99 \%$ ). $5 \mathrm{mmol}$ iodomethane was added into $10 \mathrm{~mL}$ acetonitrile solution of compound $1 \mathrm{c}(1 \mathrm{mmol})$ and the mixture solution was stirred for overnight at room temperature under argon atmosphere. Then, there is a large amount of precipitate in the solution. After filtration and the precipitate was washed with THF and $n$-hexane and dried under vacuum. Compound $\mathbf{1 b}$ was then received as white powder finally. ${ }^{1} \mathrm{H}$ NMR (DMSO-d $6,400 \mathrm{MHz}$ ). $\delta \mathrm{ppm}$ : $9.75(\mathrm{~s}, 1 \mathrm{H}), 8.52(\mathrm{dd}, \mathrm{J}=8$, $0.8 \mathrm{~Hz}, 1 \mathrm{H}), 8.37(\mathrm{~d}, \mathrm{~J}=8 \mathrm{~Hz}, 1 \mathrm{H}), 8.22(\mathrm{t}, \mathrm{J}=2 \mathrm{~Hz}, 1 \mathrm{H}), 8.15-8.06(\mathrm{~m}, 3 \mathrm{H}), 7.94-$ 7.90 (m, $2 \mathrm{H}), 7.76(\mathrm{td}, \mathrm{J}=7.6,0.8 \mathrm{~Hz}, 1 \mathrm{H}), 4.05$ (s, $3 \mathrm{H}) .{ }^{13} \mathrm{C}$ NMR (DMSO-d 6,101 $\mathrm{MHz}$ ). $\delta$ ppm: $138.17,136.45,136.23,135.24,133.18,131.95,131.05,130.29$, $129.32,128.84,124.93,124.28,124.23,123.48,122.18,36.36$.
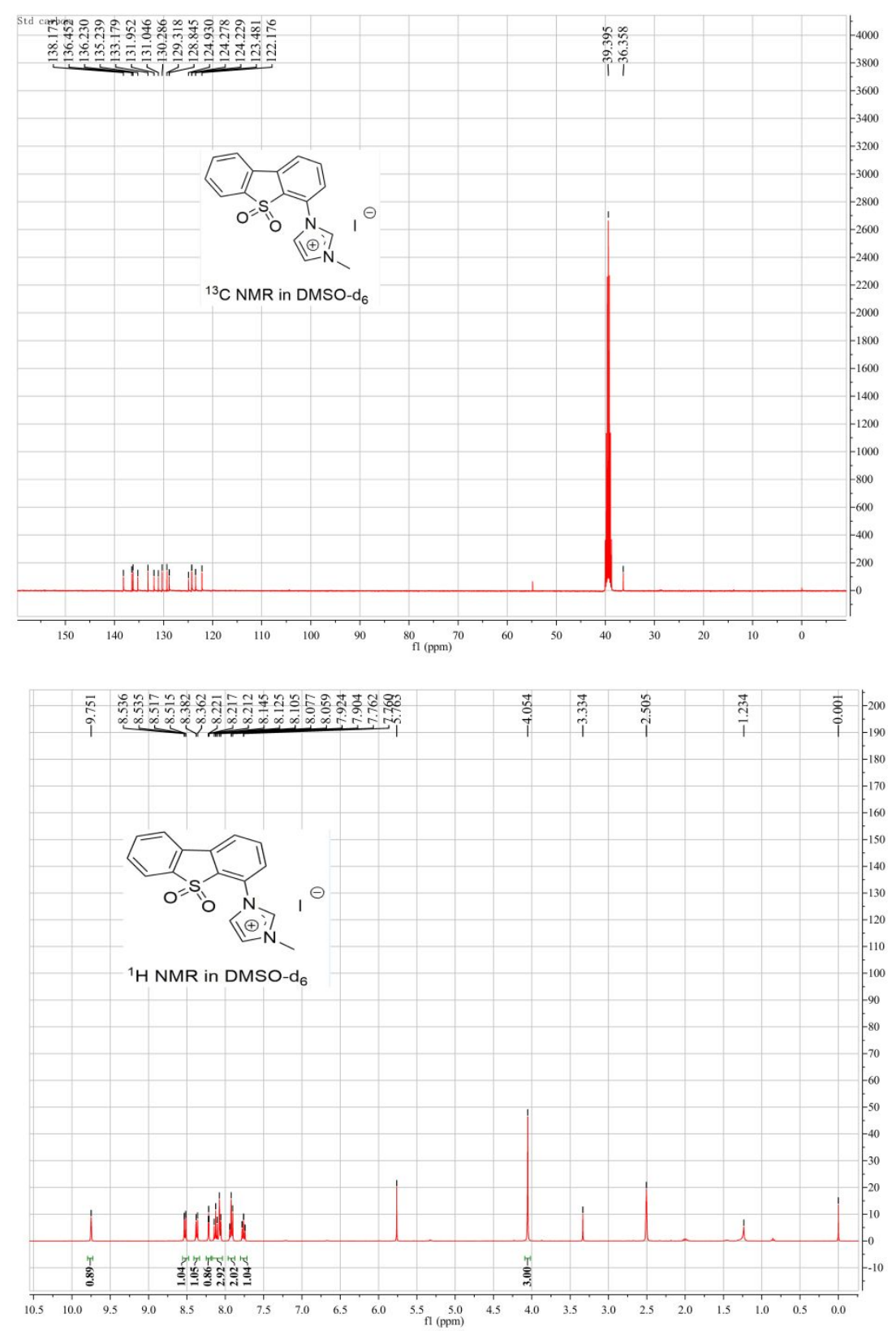

Compound 1c (Yield: 98\%).15 g hydrogen peroxide (30 wt\%) was slowly dropped to $30 \mathrm{~mL}$ glacial acetic acid solution of 4-(1H-imidazol-1-yl)dibenzo[b,d]thiophene 5oxide $(10 \mathrm{mmol})$ at $0{ }^{\circ} \mathrm{C}$. After the addition, the temperature is raised to room temperature and the mixture solution are still kept stirring until the starting materials 
are almost consumed (TLC detection, new product was detected upon the original material in the TLC plate). The mixture solution was neutralized with $10 \mathrm{wt} \%$ aq. $\mathrm{NaHCO}_{3}$ solution. Then, the solution was extracted with dichloromethane and the organic phase are dried with anhydrous $\mathrm{Na}_{2} \mathrm{SO}_{4}$. The concentrated organic phase is purified using silica gel column chromatography with an eluent solution of dichloromethane/petroleum ether and the ideal product is received as white powder. ${ }^{1} \mathrm{H}$ NMR $\left(\mathrm{CDCl}_{3}, 400 \mathrm{MHz}\right) . \delta \mathrm{ppm}: 8.10$ (s, $\left.1 \mathrm{H}\right), 7.90-7.85(\mathrm{~m}, 3 \mathrm{H})$, 7.79-7.72 (m, 2 $\mathrm{H}), 7.65-7.60(\mathrm{~m}, 2 \mathrm{H}), 7.46(\mathrm{dd}, \mathrm{J}=8,0.8 \mathrm{~Hz}, 1 \mathrm{H}), 7.33(\mathrm{~s}, 1 \mathrm{H}) .{ }^{13} \mathrm{C} \mathrm{NMR}\left(\mathrm{CDCl}_{3}\right.$, $101 \mathrm{MHz}) . \delta$ ppm:135.09, 134.12, 131.17, 130.74, 126.59, 122.26, 121.80, 120.73. Tof-MS, m/z calculated 283.0536, experimental, 283.0532.
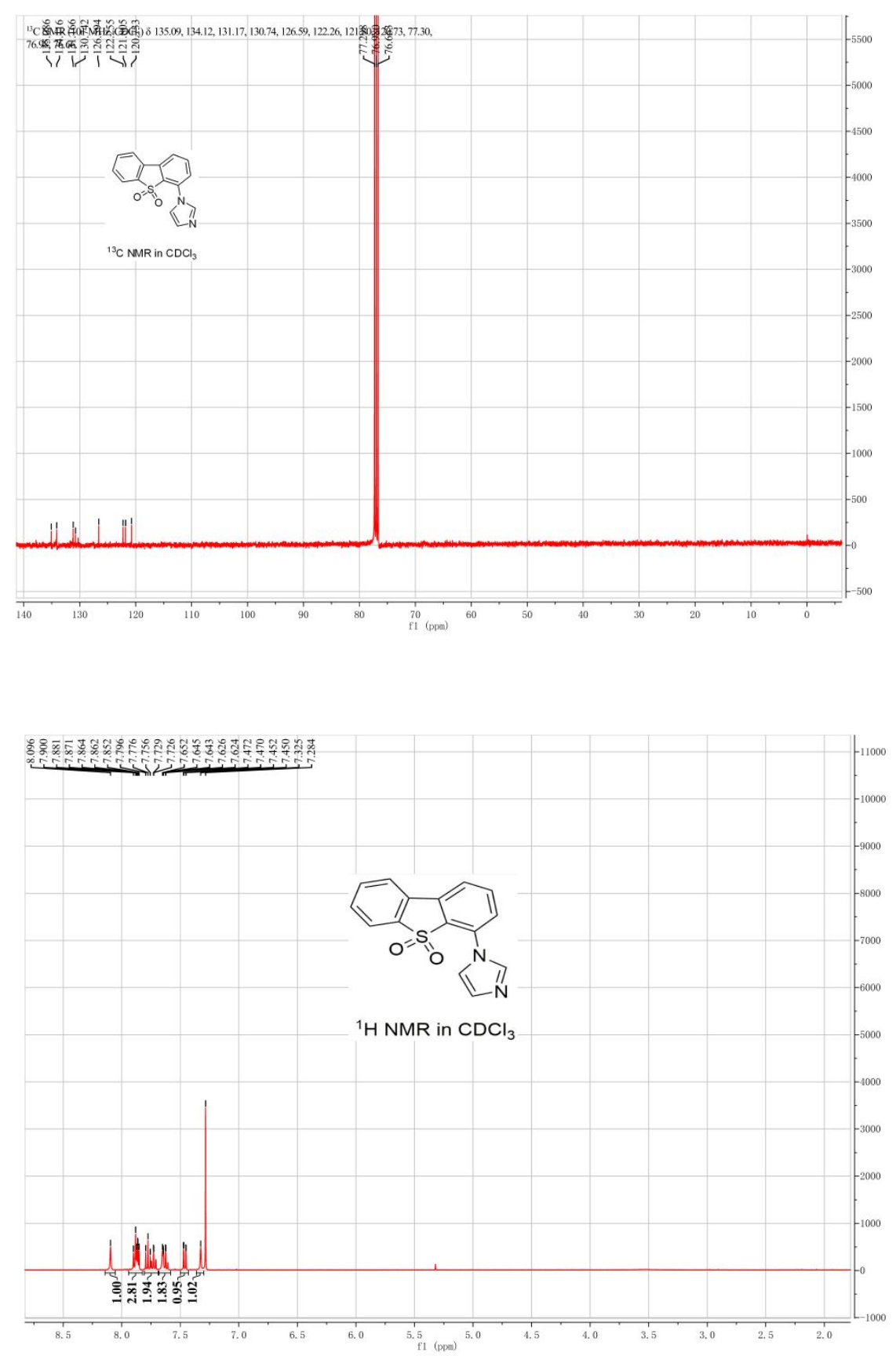

Compound 1d (Yield:98\%). This compound was synthesized by the same procedure of compound 1a just substituting the original material of (bromomethyl)benzene with bromoethane. ${ }^{1} \mathrm{H}$ NMR (DMSO- $\mathrm{d}_{6}, 400 \mathrm{MHz}$ ). $\delta$ ppm: $9.82(\mathrm{~s}, 1 \mathrm{H}), 8.52$ (d, J=7.2 Hz, 
$1 \mathrm{H}), 8.36(\mathrm{~d}, \mathrm{~J}=7.6 \mathrm{~Hz}, 1 \mathrm{H}), 8.24(\mathrm{t}, \mathrm{J}=2 \mathrm{~Hz}, 1 \mathrm{H}), 8.18(\mathrm{t}, \mathrm{J}=2 \mathrm{~Hz}, 1 \mathrm{H}), 8.13(\mathrm{t}, \mathrm{J}=8$ $\mathrm{Hz}, 1 \mathrm{H}), 8.06$ (d, J=7.6 Hz, $1 \mathrm{H}), 7.97-7.89(\mathrm{~m}, 2 \mathrm{H}), 7.76(\mathrm{t}, \mathrm{J}=7.6 \mathrm{~Hz}, 1 \mathrm{H}), 4.41$ (q, $\mathrm{J}=3.2 \mathrm{~Hz}, 2 \mathrm{H}$ ), 1.54 (t, J=3.2 Hz, $3 \mathrm{H}$ ). ${ }^{13} \mathrm{C}$ NMR (DMSO-d $\left.6,101 \mathrm{MHz}\right) . \delta \mathrm{ppm}$ : $138.03,137.03,136.83,135.84,133.74,132.55,131.72,130.94,129.90,129.43$, $125.53,124.99,124.08,123.41,122.78,45.57,15.45$.
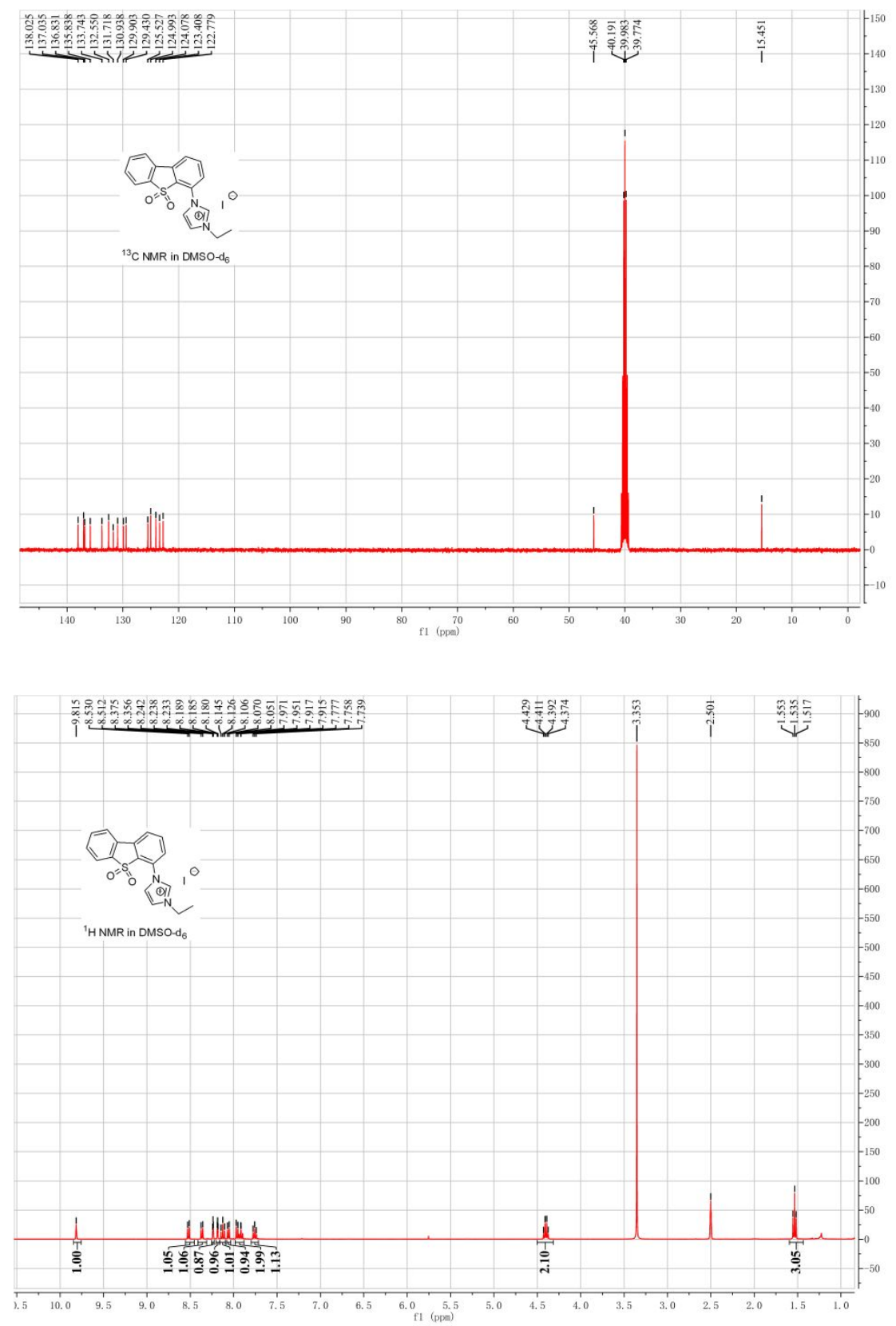

Compound 1e (Yield: 96\%). This compound was synthesized using the same procedure of compound $\mathbf{1 b}$ just substituting the starting material of compound $\mathbf{1 c}$ with 4-(1H-imidazol-1-yl)dibenzo[b,d]thiophene 5-oxide. ${ }^{1} \mathrm{H}$ NMR (DMSO- $\left.\mathrm{d}_{6}, 400 \mathrm{MHz}\right) . \delta$ ppm: 9.77 (s, $1 \mathrm{H}), 8.43(\mathrm{dd}, \mathrm{J}=7.6,0.8 \mathrm{~Hz}, 1 \mathrm{H}), 8.33$ (t, J=2 Hz, $1 \mathrm{H}), 8.28$ (d, J=7.2 $\mathrm{Hz}, 1 \mathrm{H}), 8.15(\mathrm{~d}, \mathrm{~J}=2 \mathrm{~Hz}, 1 \mathrm{H}), 8.08(\mathrm{t}, \mathrm{J}=1.6 \mathrm{~Hz}, 1 \mathrm{H}), 8.03$ (t, J=7.6 Hz, $1 \mathrm{H}), 7.84-$ 7.80 (m, $2 \mathrm{H}$ ), 7.71-7.67 (td, J=7.6, $1.2 \mathrm{~Hz}, 1 \mathrm{H}$ ), 4.04 (s, $3 \mathrm{H}$ ). ${ }^{13} \mathrm{C}$ NMR (DMSO-d 6 , $101 \mathrm{MHz}$ ). $\delta$ ppm: 144.13, 139.46, 139.33, 138.04, 135.84, 135.15, 134.44, 133.54, $130.96,127.78,126.84,124.73,124.65,123.63,123.55,36.46$. 

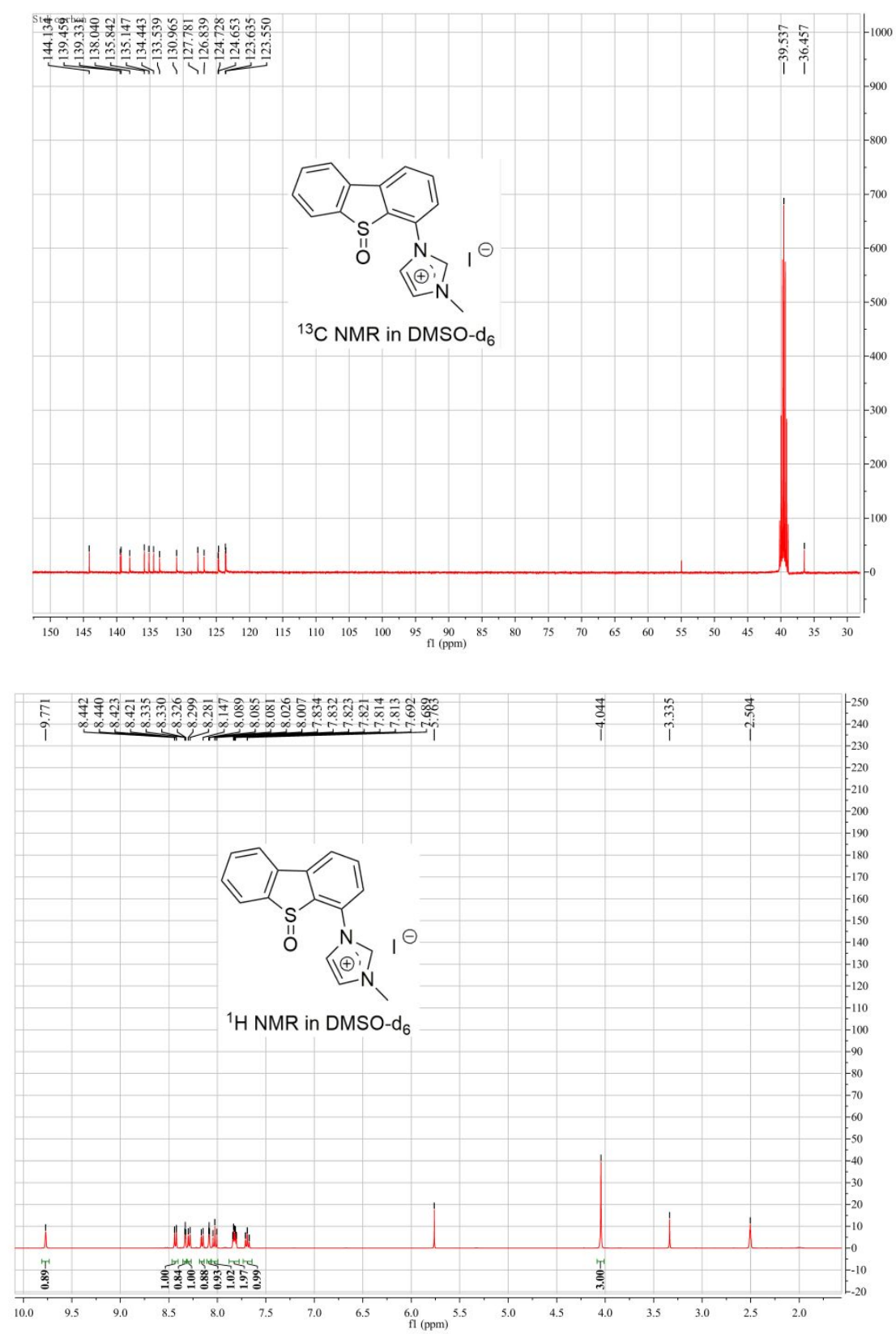

Compound 2a (Yield: 95\%). This compound was synthesized using the same procedure of compound 1c just with 4- $(1 \mathrm{H}-$ benzo[d]imidazol-1$\mathrm{yl})$ dibenzo[b,d]thiophene 5-oxide in the place of 4-(1H-imidazol-1$\mathrm{yl}$ )dibenzo[b,d]thiophene 5-oxide. ${ }^{1} \mathrm{H}$ NMR $\left(\mathrm{CDCl}_{3}, 400 \mathrm{MHz}\right) . \delta \mathrm{ppm}: 8.66(\mathrm{~s}, 1 \mathrm{H})$, 8.00-7.90 (m, $3 \mathrm{H}), 7.88-7.82(\mathrm{~m}, 2 \mathrm{H}), 7.76-7.71$ (td, J=7.6, $1.2 \mathrm{~Hz}, 1 \mathrm{H}), 7.64-7.61$ $(\mathrm{m}, 2 \mathrm{H}), 7.44-7.38(\mathrm{~m}, 3 \mathrm{H}) .{ }^{13} \mathrm{C}$ NMR $\left(\mathrm{CDCl}_{3}, 101 \mathrm{MHz}\right) . \delta \mathrm{ppm}: 143.26,137.83$, $135.13,134.56,134.21,133.14,131.27,130.20,128.10,124.50,123.87,122.33$, $121.91,121.54,120.46,110.66$. 

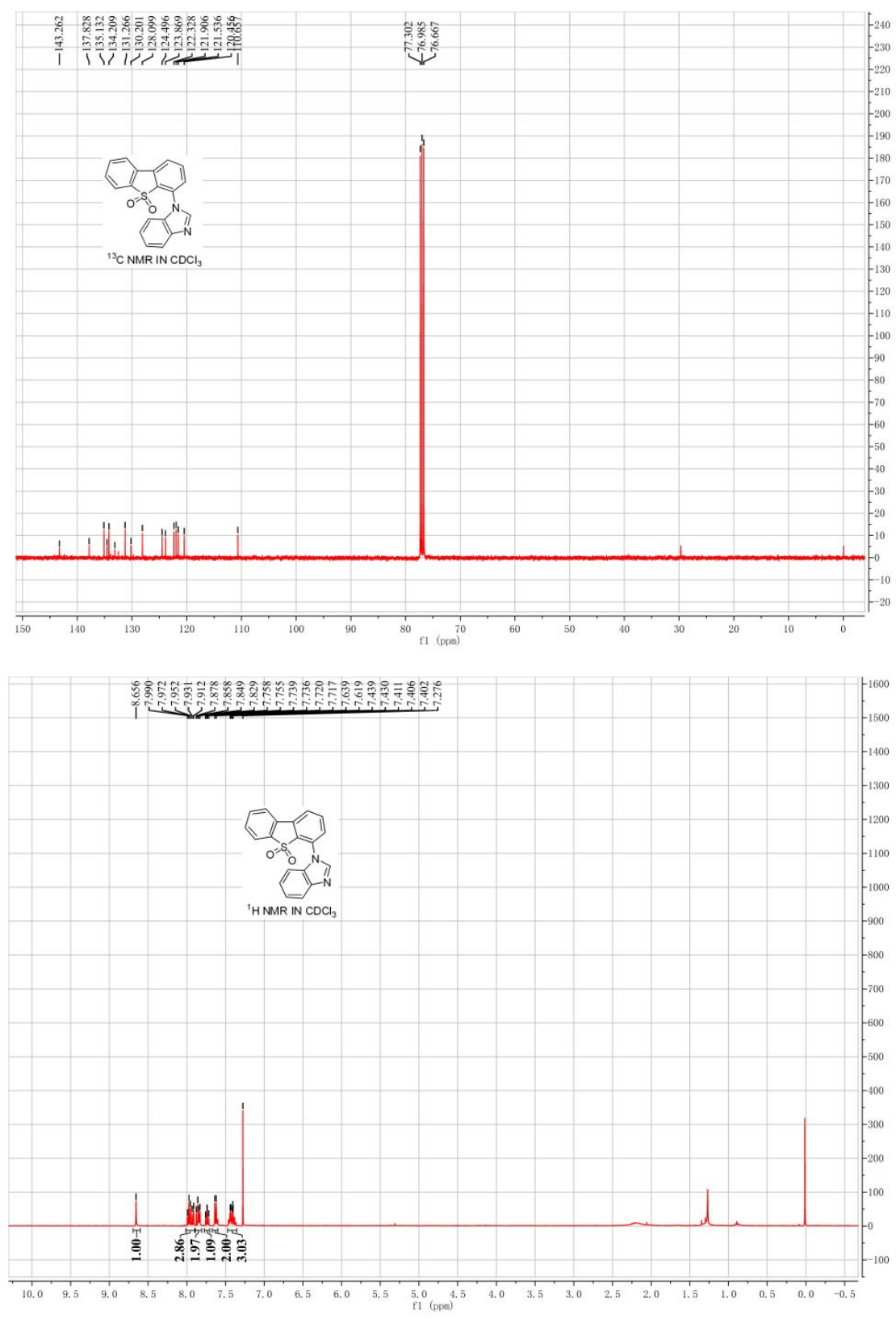

Compound 2b (Yield: 99\%). This compound was synthesized using the same procedure of $1 \mathrm{e}$ just substituting the starting material of 4 - $(1 \mathrm{H}$-imidazol-1$\mathrm{yl})$ dibenzo[b,d]thiophene 5-oxide with 4-(1H-benzo[d]imidazol-1yl)dibenzo[b,d]thiophene 5-oxide. ${ }^{1} \mathrm{H}$ NMR (DMSO- $\mathrm{d}_{6}, 400 \mathrm{MHz}$ ). $\delta \mathrm{ppm}$ : 10.28 (s, 1 H), 8.53 (dd, J=8 Hz, $1 \mathrm{H}$ ), 8.31 (dd, J=8 Hz, $1 \mathrm{H}), 8.23$ (dd, J=8.4 Hz, $1 \mathrm{H}), 8.09$ (m, $2 \mathrm{H}), 7.92(\mathrm{~d}, \mathrm{~J}=7.6 \mathrm{~Hz}, 2 \mathrm{H}), 7.81(\mathrm{q}, \mathrm{J}=7.6 \mathrm{~Hz}, 2 \mathrm{H}), 7.75(\mathrm{t}, \mathrm{J}=8 \mathrm{~Hz}, 1 \mathrm{H}), 7.68(\mathrm{t}$, $\mathrm{J}=7.6 \mathrm{~Hz}, 1 \mathrm{H}$ ), 4.28 (s, $3 \mathrm{H}$ ). ${ }^{13} \mathrm{C}$ NMR (DMSO-d $6,101 \mathrm{MHz}$ ). $\delta \mathrm{ppm}: 144.95,144.27$, $141.56,140.05,136.43,135.74,133.87,132.42,132.03,131.29,128.81,128.15$, $127.82,125.85,123.95,114.58,114.50,104.99,34.37$. 

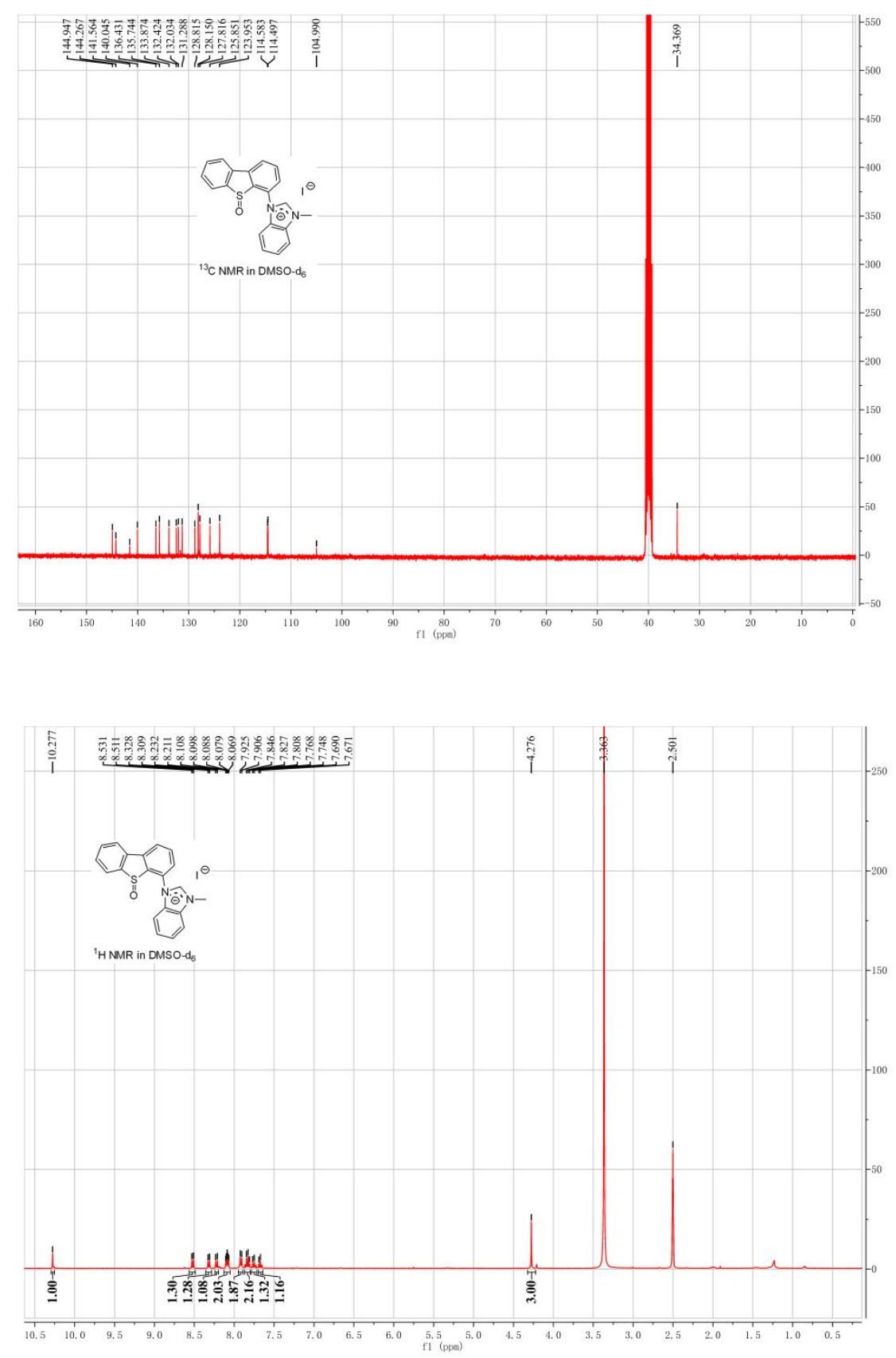

Compound 2c (Yield: 98\%). This compound was synthesized using the same procedure of $\mathbf{1 b}$ just substituting the starting material of compound $1 \mathrm{c}$ with compound 2a. ${ }^{1} \mathrm{H}$ NMR (DMSO-d $6,400 \mathrm{MHz}$ ). $\delta$ ppm: 10.29 (s, $\left.1 \mathrm{H}\right), 8.62(\mathrm{~d}, \mathrm{~J}=8 \mathrm{~Hz}, 1 \mathrm{H}), 8.39$ (d, J=8 Hz, $1 \mathrm{H}), 8.22-8.15(\mathrm{~m}, 2 \mathrm{H}), 8.00-7.90(\mathrm{~m}, 3 \mathrm{H}), 7.84(\mathrm{t}, \mathrm{J}=8 \mathrm{~Hz}, 1 \mathrm{H}), 7.76-$ $7.69(\mathrm{~m}, 3 \mathrm{H}), 4.31$ (s, $3 \mathrm{H}) .{ }^{13} \mathrm{C}$ NMR (DMSO-d $\left.6,101 \mathrm{MHz}\right) . \delta \mathrm{ppm}: 144.37,137.34$, 136.96, 135.82, 134.02, 132.86, 132.51, 131.70, 131.03, 130.01, 128.35, 128.24, $127.81,126.31,124.09,122.72,114.54,114.34,34.45$. 

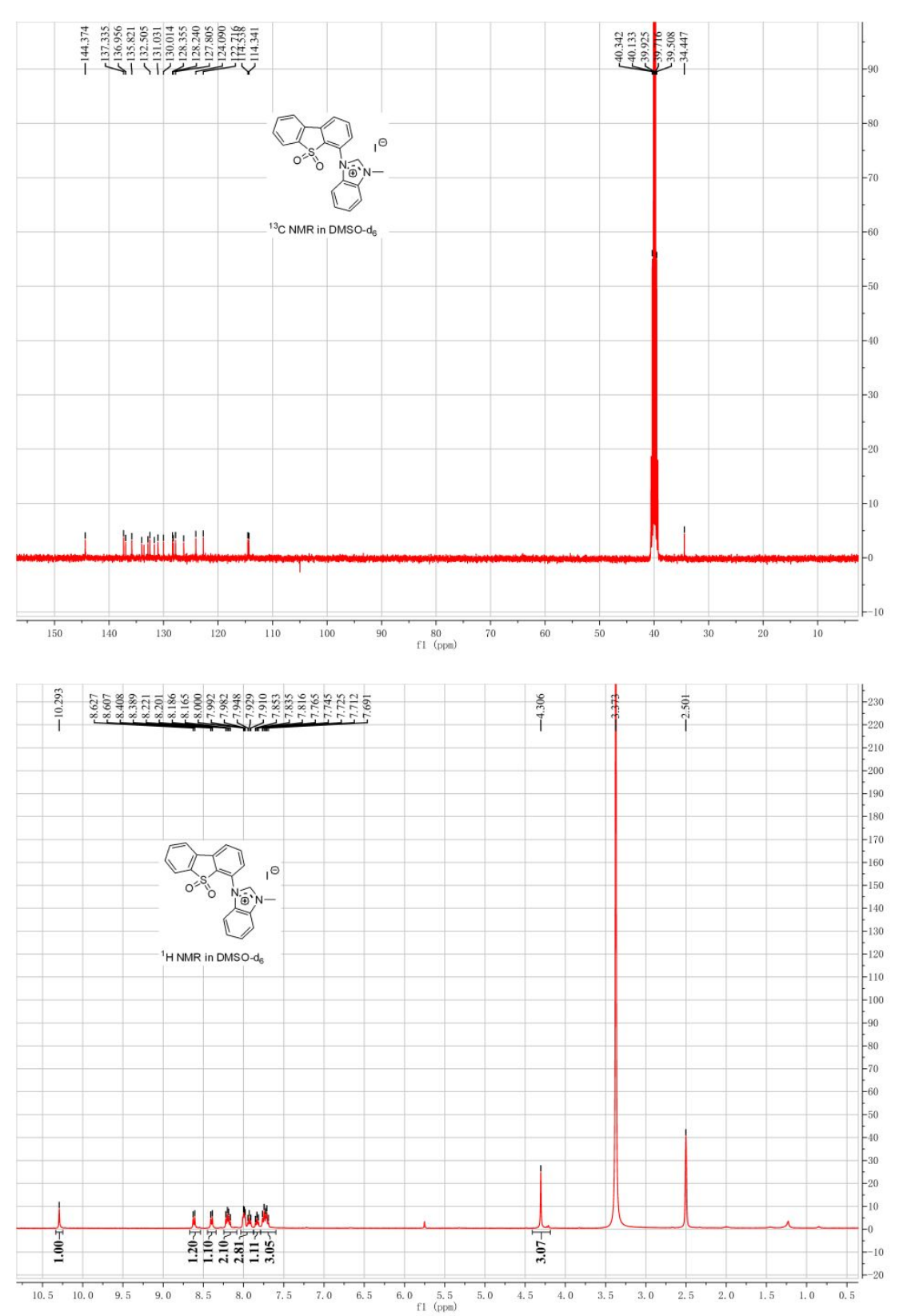

Compound 3a (Yield: 99\%). $5 \mathrm{mmol}$ iodomethane was added into $10 \mathrm{~mL}$ acetonitrile solution of compound $\mathbf{3 b}(1 \mathrm{mmol})$ and the mixture solution was stirred for overnight at room temperature under argon atmosphere. Then, there is a large amount of precipitate in the solution. After filtration and the precipitate was washed with THF and $n$-hexane and dried under vacuum. Compound $3 \mathbf{a}$ was then received as white powder finally. ${ }^{1} \mathrm{H}$ NMR (DMSO-d $\mathrm{d}_{6}, 400 \mathrm{MHz}$ ). $\delta$ ppm: $9.93(\mathrm{~s}, 1 \mathrm{H}), 8.69(\mathrm{~d}, \mathrm{~J}=2 \mathrm{~Hz}$, $1 \mathrm{H}), 8.44(\mathrm{t}, \mathrm{J}=6 \mathrm{~Hz}, 1 \mathrm{H}), 8.36(\mathrm{~d}, \mathrm{~J}=8 \mathrm{~Hz}, 1 \mathrm{H}), 8.25(\mathrm{~d}, \mathrm{~J}=8 \mathrm{~Hz}, 1 \mathrm{H}), 8.09-7.99(\mathrm{~m}$, $3 \mathrm{H}$ ), 7.94 (t, J=8 Hz, $1 \mathrm{H}$ ), $7.76(\mathrm{t}, \mathrm{J}=8 \mathrm{~Hz}, 1 \mathrm{H}), 4.00$ (s, $3 \mathrm{H}$ ). ${ }^{13} \mathrm{C}$ NMR (DMSO-d 6 , $101 \mathrm{MHz}$ ). $\delta$ ppm: 139.88, 137.88, 137.63, 137.11, 135.44, 133.65, 132.54, 129.93, $125.18,124.65,124.43,123.62,122.85,121.51,116.90,36.88$. 

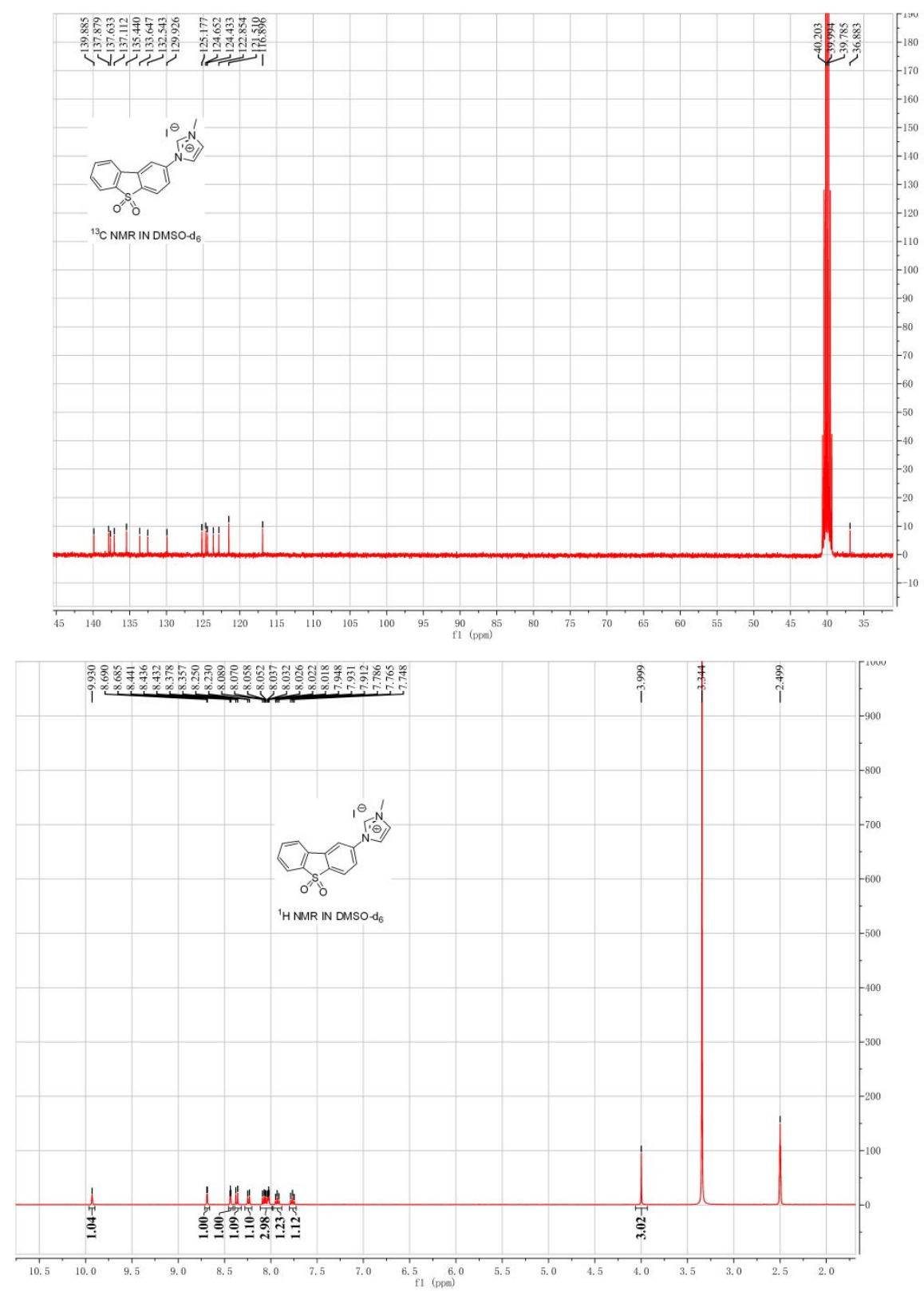

Compound $\mathbf{3 b}$ (Yield: 95\%). This compound was synthesized using the same procedure of the compound $1 \mathrm{c}$ just with $2-(1 \mathrm{H}$-imidazol-1-yl)dibenzo[b,d]thiophene 5oxide in the place of 4 - $\left(1 \mathrm{H}\right.$-imidazol-1-yl)dibenzo[b,d]thiophene 5 -oxide. ${ }^{1} \mathrm{H}$ NMR $\left(\mathrm{CDCl}_{3}, 400 \mathrm{MHz}\right)$. $\delta$ ppm: $8.01(\mathrm{~s}, 1 \mathrm{H}), 7.96(\mathrm{~d}, \mathrm{~J}=8 \mathrm{~Hz}, 1 \mathrm{H}), 7.88(\mathrm{t}, \mathrm{J}=7.2 \mathrm{~Hz}, 2 \mathrm{H})$, $7.80(\mathrm{~d}, \mathrm{~J}=1.6 \mathrm{~Hz}, 1 \mathrm{H}), 7.73(\mathrm{t}, \mathrm{J}=8 \mathrm{~Hz}, 1 \mathrm{H}), 7.64(\mathrm{t}, \mathrm{J}=8 \mathrm{~Hz}, 1 \mathrm{H}), 7.57$ (dd, J=8, 2 $\mathrm{Hz}, 1 \mathrm{H}), 7.41(\mathrm{~s}, 1 \mathrm{H}), 7.32(\mathrm{~s}, 1 \mathrm{H}) .{ }^{13} \mathrm{C} \mathrm{NMR}\left(\mathrm{CDCl}_{3}, 101 \mathrm{MHz}\right) . \delta \mathrm{ppm:}$ 141.96, 138.34, 136.24, 134.16, 131.40, 130.21, 124.17, 122.74, 122.49, 121.86, 114.15. 

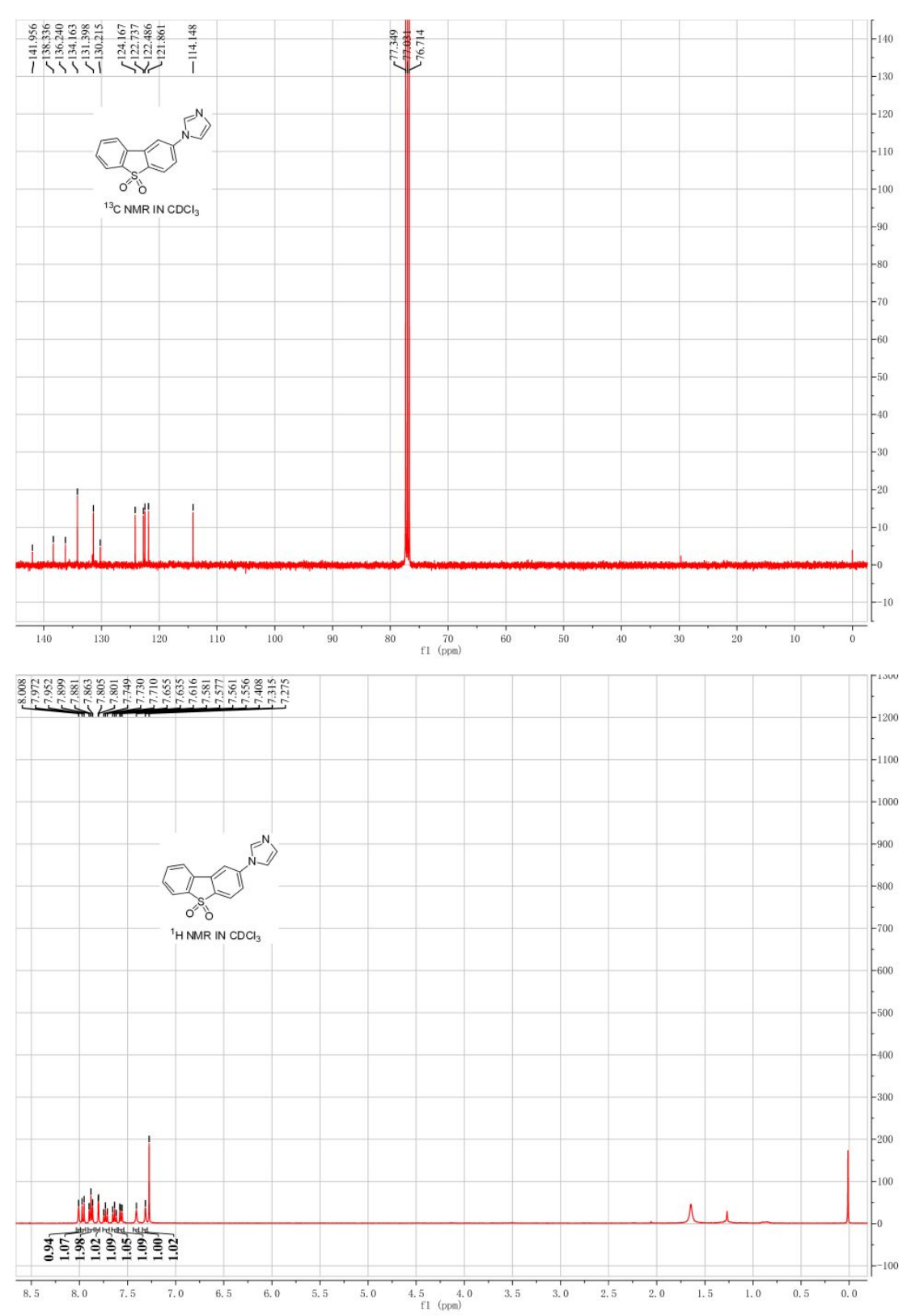

Compound 3c (Yield: 99\%). This compound was synthesized using the same procedure of $3 \mathbf{a}$ just substituting the starting material of compound $3 \mathbf{b}$ with $2-(1 \mathrm{H}-$ imidazol-1-yl)dibenzo[b,d]thiophene 5-oxide. ${ }^{1} \mathrm{H}$ NMR (DMSO-d 6 , $400 \mathrm{MHz}$ ). $\delta \mathrm{ppm}$ : $9.92(\mathrm{~s}, 1 \mathrm{H}), 8.61(\mathrm{~d}, \mathrm{~J}=2 \mathrm{~Hz}, 1 \mathrm{H}), 8.42(\mathrm{~m}, 2 \mathrm{H}), 8.18(\mathrm{dd}, \mathrm{J}=8,7.2 \mathrm{~Hz}, 2 \mathrm{H}), 8.02$ (t, $\mathrm{J}=2 \mathrm{~Hz}, 1 \mathrm{H}), 7.98$ (dd, J=8.4, $2.4 \mathrm{~Hz}, 1 \mathrm{H}), 7.84$ (td, J=8, $1 \mathrm{~Hz}, 1 \mathrm{H}), 7.69$ (td, J= 7.6, $1 \mathrm{~Hz}, 1 \mathrm{H}$ ), 4.00 (s, $3 \mathrm{H}$ ). ${ }^{13} \mathrm{C}$ NMR (DMSO-d, $\left.101 \mathrm{MHz}\right) . \delta \mathrm{ppm}: 145.94,139.22$, 138.71 , 136.97, 135.73, 133.65, 131.33, 129.92, 128.36, 125.14, 123.55, 123.08, $121.50,116.59,36.83$. 

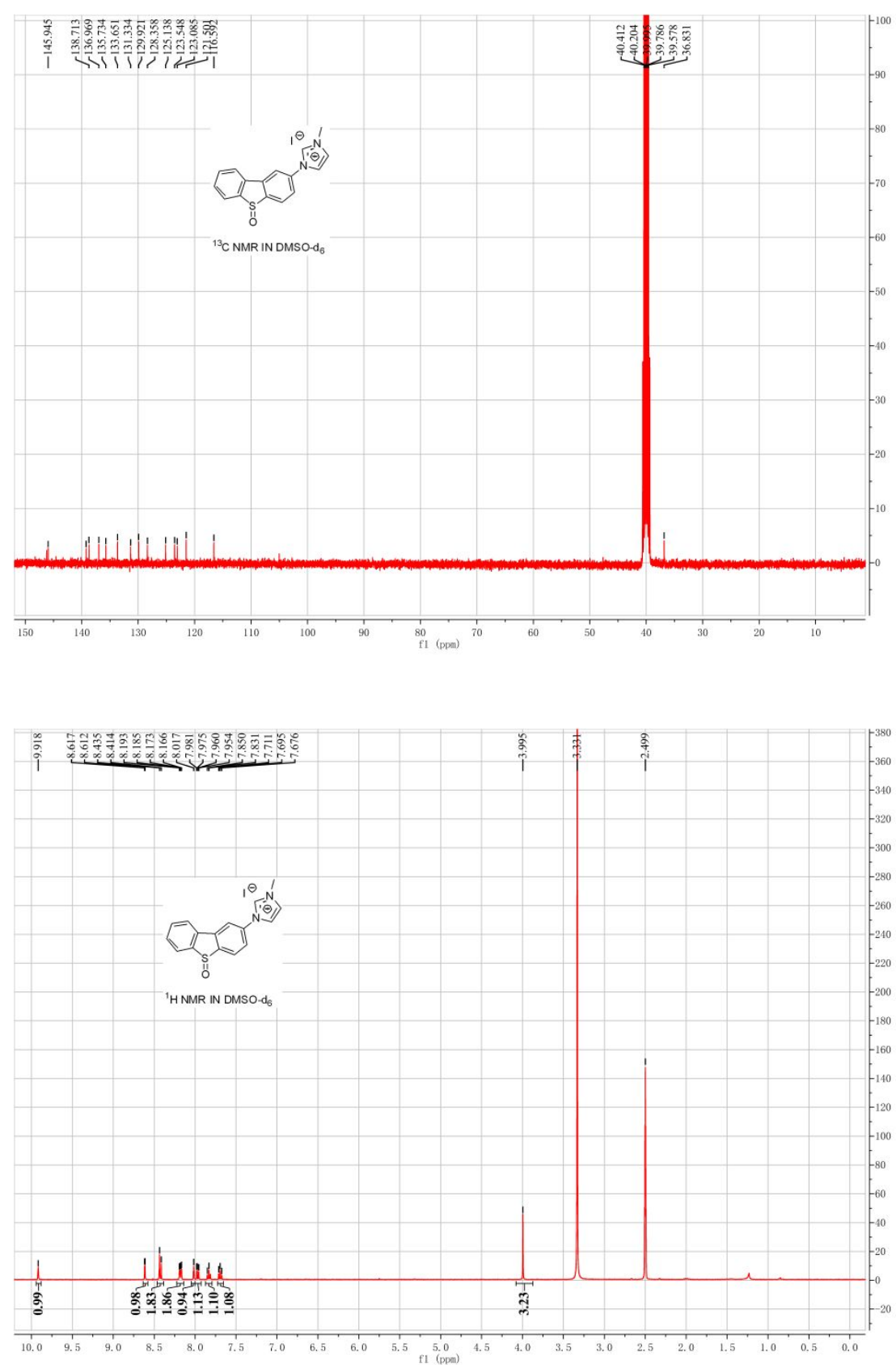

\section{Cellular thermal shift assay}

Cellular thermal shift assay was performed to monitor the target engagement of compounds in HeLa cells. Briefly, cell lysates from $2 \times 10^{6}$ HeLa cells were collected, diluted in PBS and separated in same aliquots. Each aliquot was treated with 1a (10 $\mu \mathrm{M})$ or DMSO. $30 \mathrm{~min}$ after incubation at room temperature, the complex-treated lysates were divided into $50 \mu \mathrm{l}$ in each of tubes and heated individually at different temperatures (Veriti thermal cycler, Applied Biosystems/Life Technologies). The heated lysates were centrifuged and the supernatants were analyzed by SDS-PAGE followed by immunoblotting analysis by probing with Pin1 antibody and GAPDH antibody (Cell Signaling Technology).

\section{Co-immunoprecipitation}

The inhibition of Pin1-p65 interactions was investigated using a coimmunoprecipitation assay following the manufacturer's instructions. Briefly, HeLa 
cells $\left(1 \times 10^{6}\right.$ cells/well) were treated with indicated concentrations of $1 \mathrm{a}(1$ and $10 \mu \mathrm{M})$ and DMSO for $12 \mathrm{~h}$. After cell lysis and protein lysate separation, $100 \mu \mathrm{g}$ of total protein was incubated with p65 antibody at $4{ }^{\circ} \mathrm{C}$ overnight. The proteins were immunoprecipitated using agarose beads. The levels of co-precipitated Pin1 were analyzed using Western blotting.

\section{Transfection with plasmids.}

Transfection with plasmids was performed as previously. ${ }^{2}$ Briefly, 293T cells were seed at a density of $6 \times 10^{5}$ cell in a culture dish overnight. The cells were cotransfected with recombinant plasmids pCMV6-Pin1-wild-type for $36 \mathrm{~h}$ in serum-free DMEM medium using TurboFect Transfection Reagent. Then, the transfected cells were treated with an indicated concentration of $1 \mathrm{a}$ in $1 \%$ FBS medium for $72 \mathrm{~h}$.

\section{Western blotting}

HeLa cells were seeded at a density of $6 \times 10^{5}$ cell in a 6 -well plate overnight. Cells were treated with $1 \mathrm{a}$ (in $0.1 \%$ DMSO), PiB, or vehicle control in $1 \%$ FBS medium for an additional $12 \mathrm{~h}$. Cells were lysed, and protein samples were collected. Protein concentration was determined by BCA protein assay kit (Thermo Scientific). $30 \mu \mathrm{g}$ of proteins samples were resolved on a 10\% SDS/PAGE gel and transferred to a polvinylidene fluoride (PVDF) membrane. Blots were blocked in $5 \%$ none-fat dry milk with TBS containing $0.1 \%$ Tween-20 for $1 \mathrm{~h}$, the membranes were subsequently treated with primary antibodies to p65, phospho-p65(Thr254), Erk1/2, c-Jun, PKM2, Histone $\mathrm{H} 3$ and GAPDH with gentle agitation overnight at $4{ }^{\circ} \mathrm{C}$. Then, membranes were washed five time with TBST. After incubation with secondary antibody for $1 \mathrm{~h}$. Proteins bands were detected using enhanced chemiluminescent Plus reagents (GE Healthcare) and analyzed by Image Lab.

\section{Knockdown assay}

HeLa cells were seeded in 6-well plates at 80\% confluence in DMEM medium for 24 h. Lipo2000 reagent and Pin1 siRNA was gently mixed and incubated for 20 min at room temperature. Then, $500 \mu \mathrm{L}$ of the Lipo2000/siRNA mixture were added to each well. Cells were incubated at $37{ }^{\circ} \mathrm{C}$ in a $\mathrm{CO}_{2}$ incubator for $48 \mathrm{~h}$ post-transfection before further research.

\section{Half-life assay}

After treated with $1 \mathrm{a}$ for $12 \mathrm{~h}$, HeLa cells were treated with $50 \mu \mathrm{g} / \mathrm{ml}$ cycloheximide (CHX, Sigma-Aldrich) for the indicated time periods. p65 levels were determined by Western blot analysis and quantified by densitometry analysis.

\section{Cytotoxicity assay}

HeLa, 293T and LO2 cells were seeded at 5,000 cells per well in 96-well plates and incubated overnight at $37^{\circ} \mathrm{C}$. The cells were treated with $1 \mathrm{a}$ at final concentration from 0.1 to $100 \mu \mathrm{M}$ for $72 \mathrm{~h}$. Then MTT reagent was added to each well at a final concentration of $0.5 \mathrm{mg} / \mathrm{mL}$ for a further $4 \mathrm{~h}$. After then, the medium was replaced with $100 \mu \mathrm{L}$ DMSO. The viability of the cells was measured by recording the absorbance of each well at $490 \mathrm{~nm}$ using a SpectraMax M5 microplate reader after shaking the plate for 10 min at room temperature in the dark. 


\section{Cell imaging}

HeLa cells were seeded into a glass-bottomed dish ( $35 \mathrm{~mm}$ dish with $20 \mathrm{~mm}$ wells) for $24 \mathrm{~h}$, then the cells were incubated with doxorubicin in the presence or absence of $1 \mathrm{a}$ for the indicated time periods or concentrations and then washed with phosphate-buffered saline three times. The luminescence imaging of complexes in cells was carried out by a Leica TCS SP8 confocal laser scanning microscope system. The excitation wavelength was $488 \mathrm{~nm}$.

\section{Flow cytometry analysis}

HeLa cells were seeded at density of $1 \times 10^{6}$ in a 6-well plate, and were treated with 1a $(50 \mu \mathrm{M})$ for $6 \mathrm{~h}$ and then in the presence or absence of doxorubicin $(5 \mu \mathrm{M})$ for $6 \mathrm{~h}$ at $37{ }^{\circ} \mathrm{C}$. Cells were harvested and washed twice with ice-cold PBS, and then resuspended in $1 \times$ binding buffer. The samples were immediately analyzed by flow cytometry using a C6 Flow Cytometer ${ }^{\mathrm{TM}}$ system (BD Biosciences). At least $2 \times 10^{5}$ cells were analyzed for each sample. Doxorubicin was determined by fluorescence (488 $\mathrm{nm}$ excitation and $585 \mathrm{~nm}$ emission). Data were analyzed using FlowJo7.6 software.

\section{Data analysis}

All data were reported as the means of at least three separate experiments. Group comparisons between the control group and various drug treatment groups were done by a one-way ANOVA using GraphPad Prism software (Prism).

\section{References}

1. R. Rossi, F. Bellina, D. Ciucci, A. Carpita and C. Fanelli, Tetrahedron, 1998, 54, 7595-7614.

2. C. Yang, W. Wang, L. Chen, J. Liang, S. Lin, M.-Y. Lee, D.-L. Ma and C.-H. Leung, Chemical Communications, 2016, 52, 12837-12840. 


\section{Supplementary Figures}

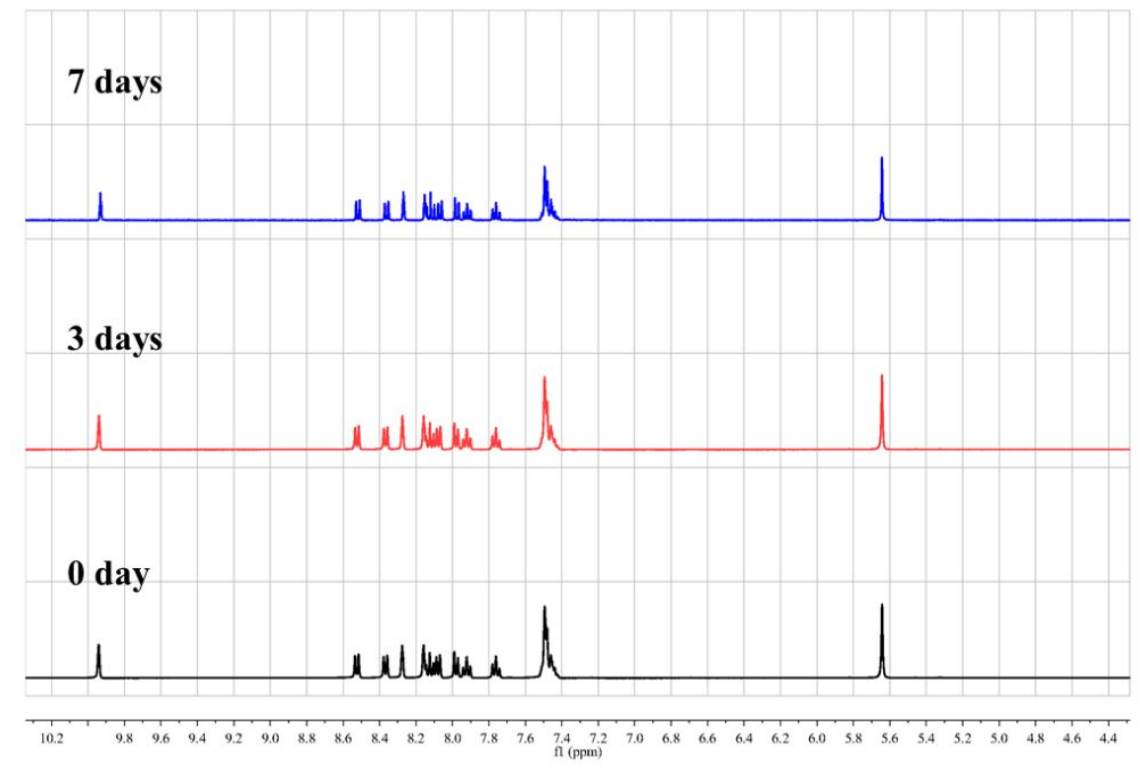

Figure S1. ${ }^{1} \mathrm{H}$ NMR spectra of compound $1 \mathrm{a}$ in DMSO-d $\mathrm{d}_{6}$ recorded at 0,3 and 7 days.

Figure S2. Pin1 activity was determined by a PPlase activity assay. Inhibition of Pin1

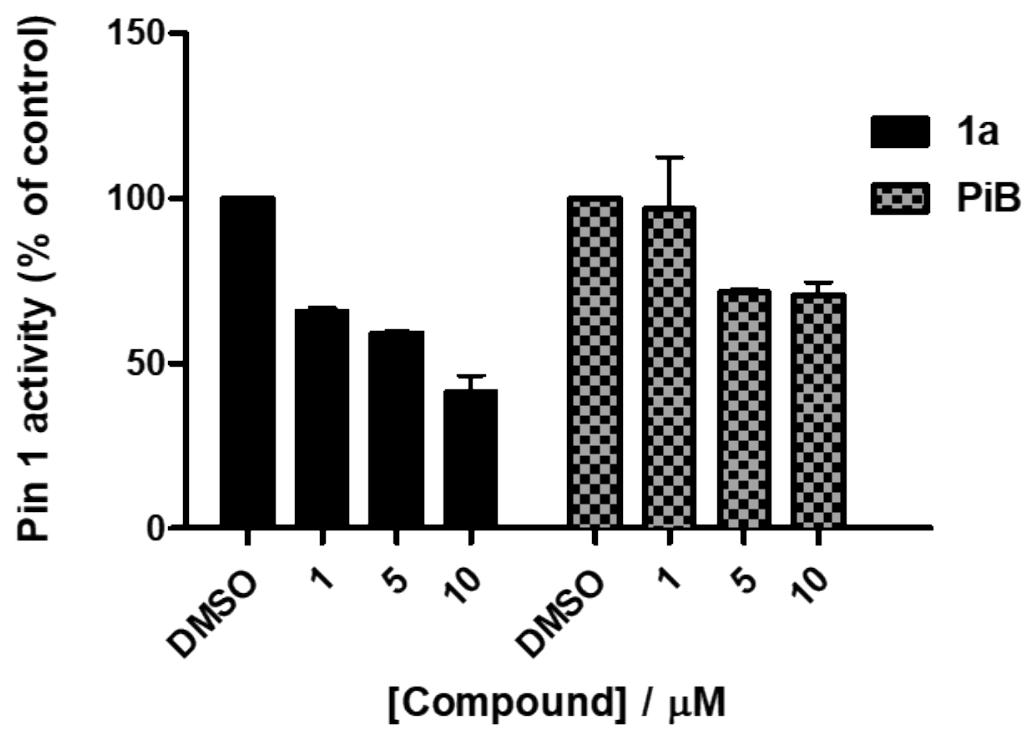

activity by compounds $1 \mathrm{a}$ and $\mathrm{PiB}$ was dose-dependent. Error bars represent standard deviation of the means of the results from three independent experiments. 
a)

\begin{tabular}{|c|c|c|c|c|c|c|}
\hline \multicolumn{7}{|c|}{ Compound 1a } \\
\hline 0 & 1 & 5 & 10 & 20 & 50 & 100 \\
\hline
\end{tabular}

Pin 1

b)

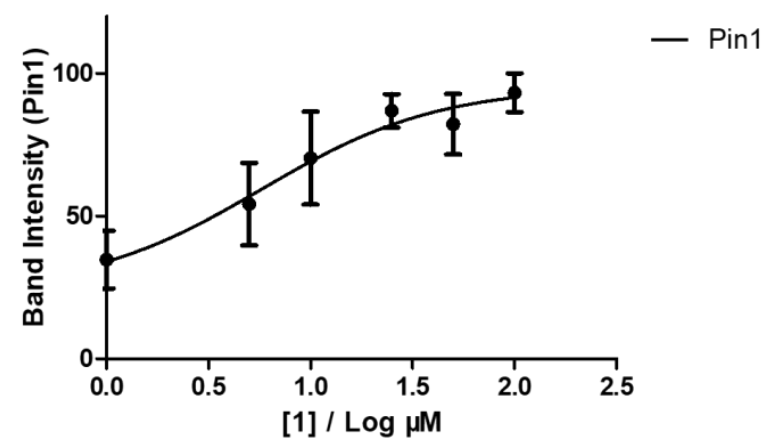

Figure S3. Compound 1a stabilizes Pin1 in Hela cells. (a) Stabilization of Pin1 by 1a at $0-100 \mu \mathrm{M}$ at $61^{\circ} \mathrm{C}$ as revealed by Western blotting. (b) The band intensity of Pin1 in the soluble fraction at different concentration of $1 \mathbf{a}$. The data were normalized to the Pin1 level of the control group(1a at $100 \mu \mathrm{M})$ and are expressed as the means \pm SD of three individual experiments. The data were analyzed using Image Lab.

a)

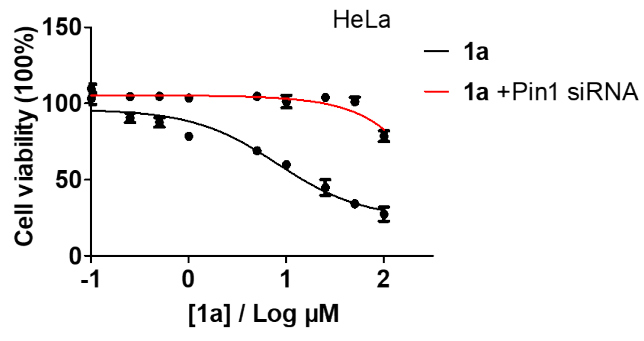

b)

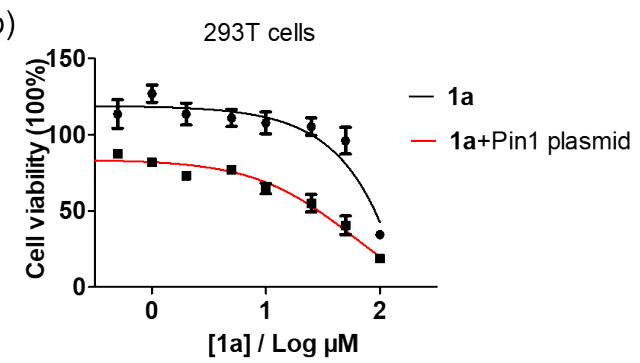

Figure S4. The cytotoxicity effect of 1a on HeLa and 293T cells as determined by the MTT assay. (a) HeLa cells and Pin1 knockdown HeLa cells were exposed to the indicated concentrations of $1 \mathrm{a}$ for 72 h. (b) Pin1 overexpressing 293T cells and 293T cells were exposed to the indicated concentrations of $1 \mathrm{a}$ for $72 \mathrm{~h}$. Error bars represent standard deviation mean of the results from three independent experiments. 


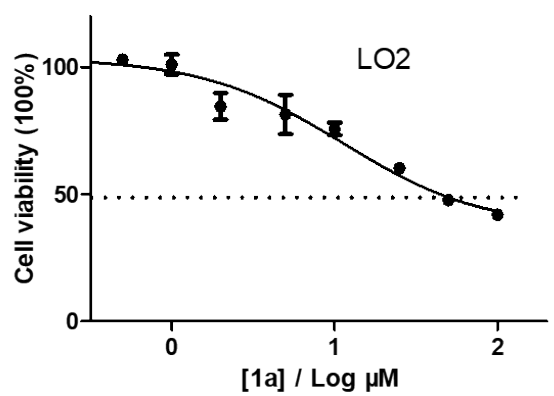

Figure S5. The cytotoxicity effect of 1a on LO2 cells as determined by the MTT assay. LO2 cells were exposed to the indicated concentrations of $1 \mathrm{a}$ for $72 \mathrm{~h}$. Error bars represent standard deviation of the means of the results from three independent experiments.

a)

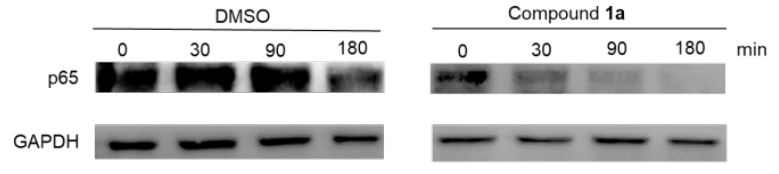

b)

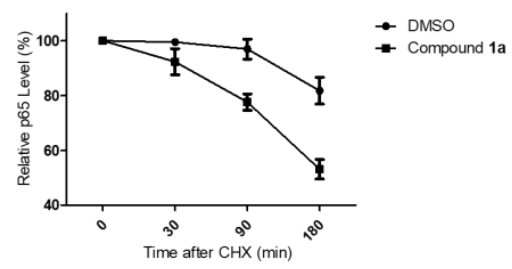

Figure S6. HeLa cells were treated with $1 \mathrm{a}(10 \mu \mathrm{M})$ for $12 \mathrm{~h}$, and then the cells were treated with cycloheximide (CHX) for $0,30,90,180$ min. (a) Equal amounts of whole cell lysates were analyzed by Western blot with a p65 antibody. GAPDH was used as an internal control. (b) The band intensity was analysed using Image Lab. Error bars represent standard deviation of the means of the results from three independent experiments. 
a)

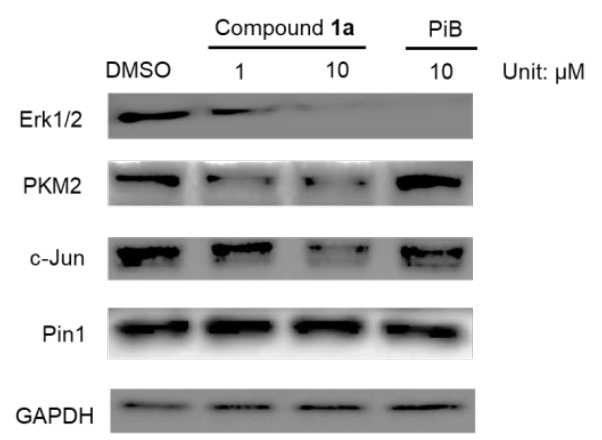

b)

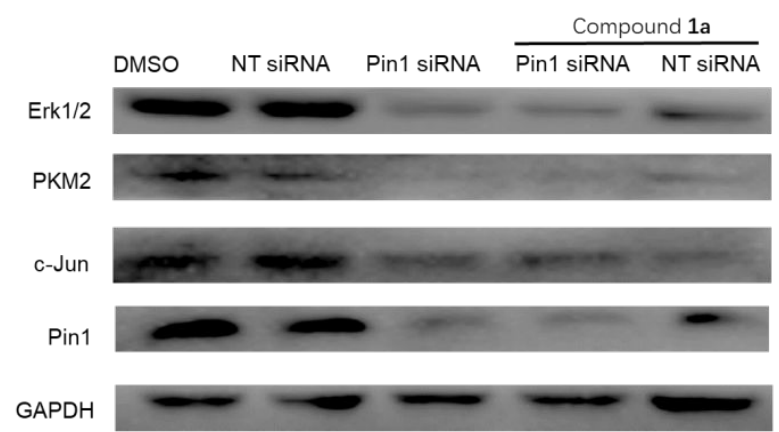

Figure S7. 1a regulated multiple oncogenic pathways associated with Pin1 inhibition in HeLa cells. (a) Western blot analysis of Erk1/2, PKM2, c-Jun and Pin1 levels in the equal amounts of whole cell lysates of HeLa cells treated with PiB or 1a for $12 \mathrm{~h}$. (b) Western blot analysis of Erk1/2, PKM2, c-Jun and Pin1 levels in the equal amounts of whole cell lysates of Pin1 knockdown HeLa cells treated with PiB or 1a for $12 \mathrm{~h}$.

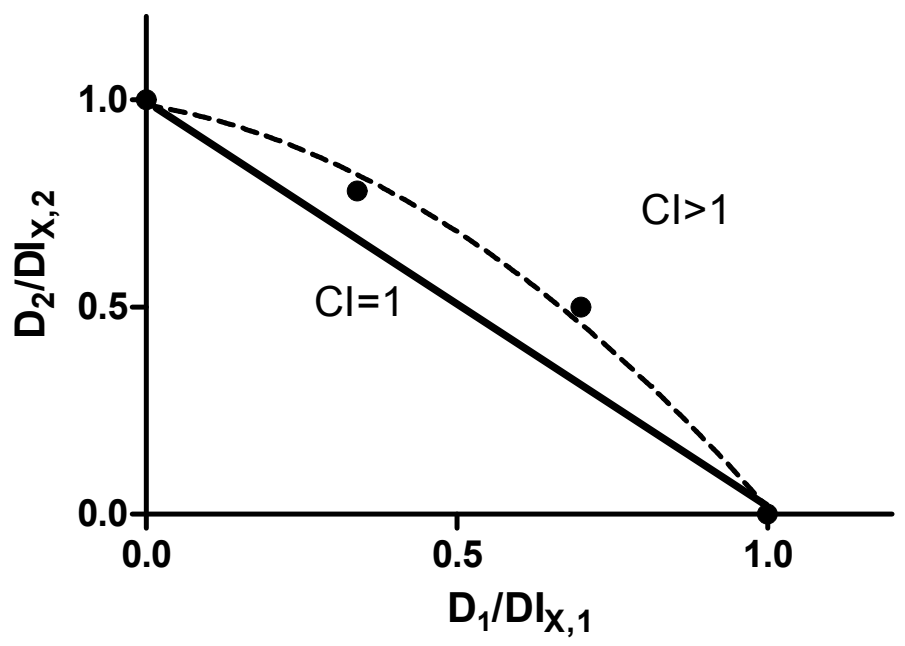

Figure S8. 1a can't enhance cisplatin efficacy. HeLa cells were treated with cisplatin in the presence or absence of $1 \mathrm{a}$ for $72 \mathrm{~h}$, and cell viability was measured using the MTT. Combination index $(\mathrm{Cl})$ values are calculated. D1 and D2 are the concentrations of 1a and cisplatin used in the combination, and $\mathrm{DL}_{\mathrm{x}, 1}$ and $\mathrm{DL}_{\mathrm{x}, 2}$ are the concentrations of a single drug to produce the same effect. 


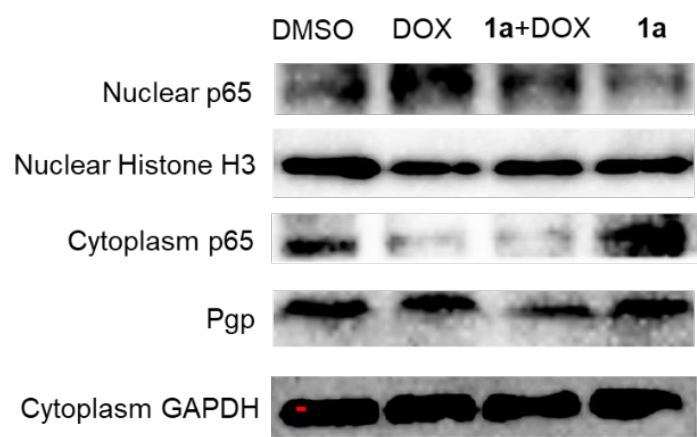

Figure S9. 1a decreased the intranuclear accumulation of p65 in HeLa cells. Hela cells incubated with compound $1 \mathrm{a}(10 \mu \mathrm{M})$ for $6 \mathrm{~h}$ and then in the presence or absence of DOX $(5 \mu \mathrm{M})$ for $6 \mathrm{~h}$ at $37^{\circ} \mathrm{C}$. Western blot analysis of p65 levels in intranuclear and cytoplasm.

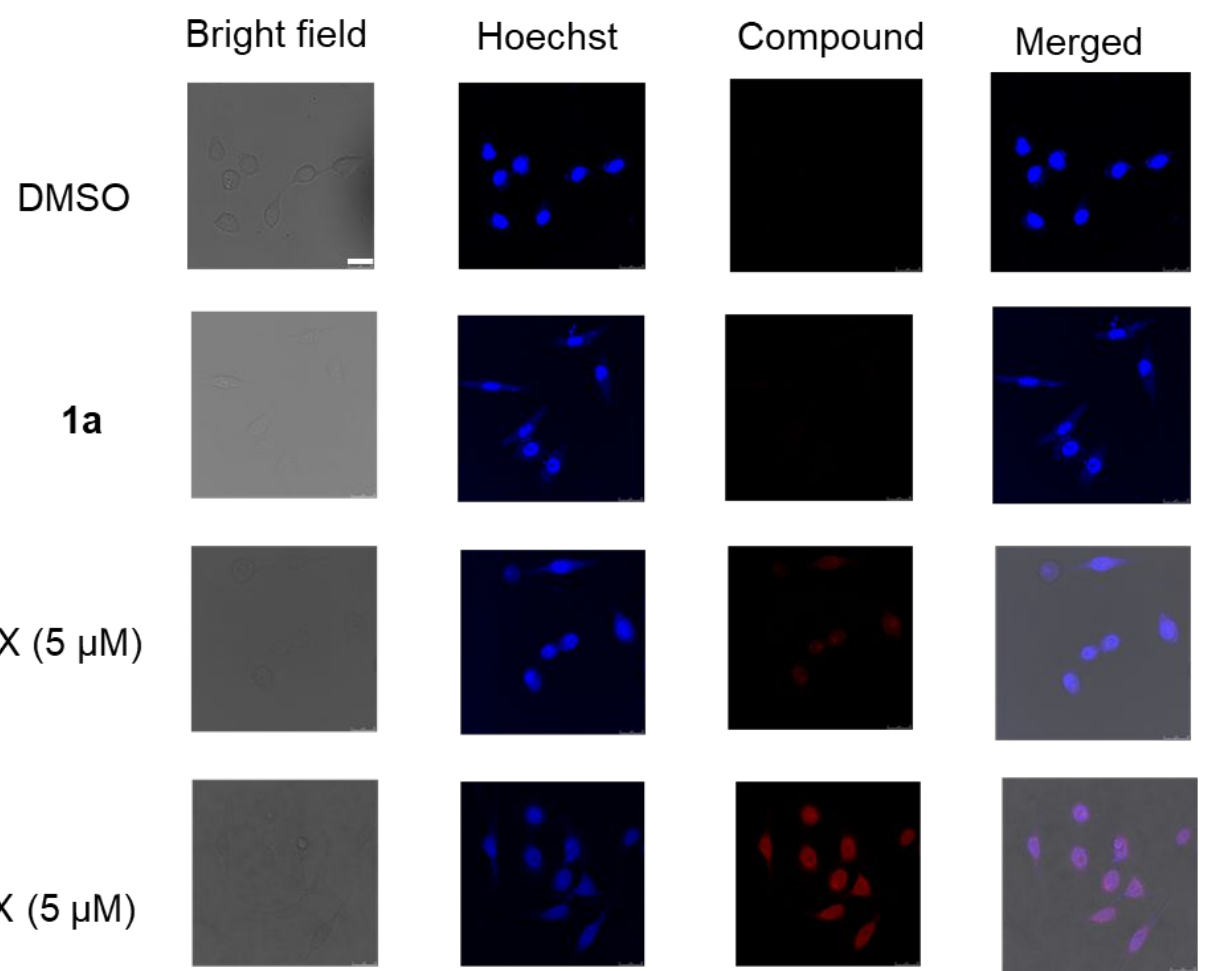

Figure S10. Luminescence and bright-field images of HeLa cells stained with $1 \mu \mathrm{M}$ of complexes $1 \mathrm{a}$ for $12 \mathrm{~h}$. Scale bar $=25 \mu \mathrm{m}$. 


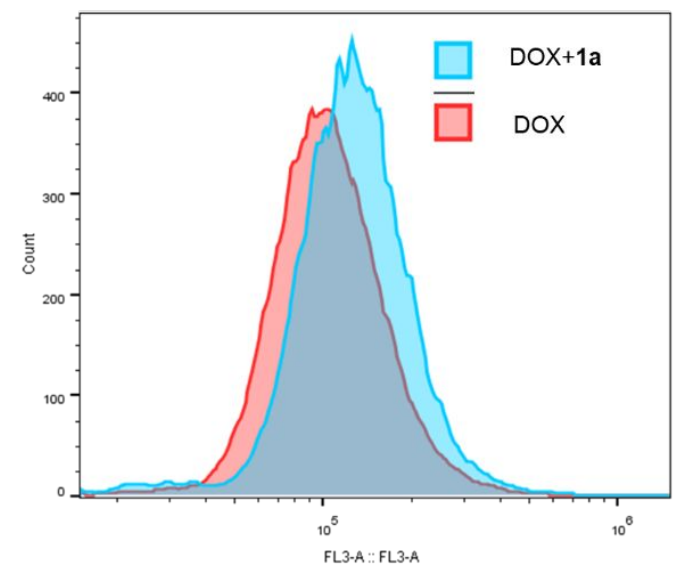

Figure S11. 1a increased the intracellular accumulation of DOX in HeLa cells. Hela cells incubated with compound $1 \mathrm{a}(50 \mu \mathrm{M})$ for $6 \mathrm{~h}$ and then in the presence or absence of DOX $(5 \mu \mathrm{M})$ for $6 \mathrm{~h}$ at $37^{\circ} \mathrm{C}$. Flow cytometric histograms of HeLa cells incubated with DOX or 1a with DOX. 